Article

\title{
Economic Evaluation of Carbon Capture and Utilization Applying the Technology of Mineral Carbonation at Coal-Fired Power Plant
}

\author{
Bong Jae Lee ${ }^{1,2} \mathbb{D}$, Jeong Il Lee ${ }^{2}$, Soo Young Yun ${ }^{2}$, Cheol-Soo Lim ${ }^{3}$ and Young-Kwon Park ${ }^{1, *}$ \\ 1 School of Environmental Engineering, University of Seoul, Seoul 02504, Korea; jae8076@ktr.or.kr \\ 2 Korea Testing \& Research Institute (KTR), Gwacheon 13810, Korea; emjilee@ktr.or.kr (J.I.L.); \\ syy927@ktr.or.kr (S.Y.Y.) \\ 3 National Institute of Environmental Research (NIER), Incheon 22689, Korea; lcs6713@korea.kr \\ * Correspondence: catalica@uos.ac.kr; Tel.: +82-2-2210-5623; Fax: +82-2-2244-2245
}

Received: 24 June 2020; Accepted: 27 July 2020; Published: 31 July 2020

check for updates

\begin{abstract}
Based on the operating data of a $40 \mathrm{tCO}_{2} /$ day (2 megawatt (MW)) class carbon capture and utilization (CCU) pilot plant, the scaled-up $400 \mathrm{tCO}_{2}$ /day $(20 \mathrm{MW})$ class CCU plant at $500 \mathrm{MW}$ power plant was economically analyzed by applying the levelized cost of energy analysis (LCOE) and $\mathrm{CO}_{2}$ avoided cost. This study shows that the LCOE and $\mathrm{CO}_{2}$ avoided cost for $400 \mathrm{tCO}_{2} /$ day class $\mathrm{CCU}$ plant of mineral carbonation technology were $26 \mathrm{USD} / \mathrm{MWh}$ and $64 \mathrm{USD} / \mathrm{tCO}_{2}$, representing low LCOE and $\mathrm{CO}_{2}$ avoided cost, compared to other carbon capture and storage CCS and CCU plants. Based on the results of this study, the $\mathrm{LCOE}$ and $\mathrm{CO}_{2}$ avoided cost may become lower by the economy of scale, even if the $\mathrm{CO}_{2}$ treatment capacity of the $\mathrm{CCU}$ plant could be extended as much as for similar businesses. Therefore, the CCU technology by mineral carbonation has an economic advantage in energy penalty, power plant construction, and operating cost over other CCS and CCU with other technology.
\end{abstract}

Keywords: carbon capture and utilization; levelized cost of energy; mineral carbonation; economic evaluation; coal-fired power plant

\section{Introduction}

Carbon dioxide $\left(\mathrm{CO}_{2}\right)$ emissions in the atmosphere from anthropogenic activities continue to grow worldwide [1-3], as $\mathrm{CO}_{2}$ emissions in the period 2010 to 2014 grew about 31.9 to $35.5 \mathrm{GtCO}_{2}$ per year, an average rate of $2.75 \%$ per year [4], escalating global warming. Various studies have been made to mitigate carbon emission to hold average global warming below $2{ }^{\circ} \mathrm{C}$ above pre-industrial levels $[5,6]$. Carbon capture and storage (CCS) and carbon capture and utilization (CCU) are evaluated by the International Energy Agency (IEA) and U.S. Energy Information Administration (EIA) as two of the most cost-effective methods for climate change mitigation among various technologies [7]. CCS permanently captures and stores $\mathrm{CO}_{2}$ to reduce greenhouse gas from coal-fired power plants or cement manufacturing facilities [8]. $\mathrm{CCU}$ involves chemical reaction, converting $\mathrm{CO}_{2}$ into valuable chemical compounds [9].

$\mathrm{CCU}$ by mineral carbonation technology, also called $\mathrm{CO}_{2}$ mineralization, is a less explored method of sequestering $\mathrm{CO}_{2}$ compared to other CCS methods, such as geological sequestration [10-12], ocean disposal [13-15], and biological fixation [16-18]. Mineral carbonation involves the chemical conversion of $\mathrm{CO}_{2}$ to solid inorganic carbonates permanently fixing carbon with a negligible risk of return to the atmosphere without having a great impact on the surrounding environment and ecosystems $[19,20]$. 
As CCS and CCU are relatively recent technologies, their effectiveness still needs to be analyzed. Large-scale CCS projects were mostly based on enhanced oil recovery, whereby $\mathrm{CO}_{2}$ is used to obtain the last remains of an oil field by injection of gaseous, liquid, or supercritical $\mathrm{CO}_{2}$ into subsurface reservoirs inducing the geological storage of $\mathrm{CO}_{2}$ in porous rocks, which was proved to be effective for cutting the $\mathrm{CO}_{2}$ emission but still remains to be studied for their cost-effectiveness compared to others technologies [21-23]. Also, IEA has published a research report, "cost and performance of carbon dioxide capture from power generation, IEA, 2011," comparing the economic feasibility of CCS-applied technologies (post-combustion, pre-combustion, oxy-combustion) between the levelized cost of energy analysis (LCOE) and $\mathrm{CO}_{2}$ avoided cost [24]. The economic evaluation of CCS has been made on the assessment method of the expectation of the energy penalty for applying CCS technology [25], comparing LCOE and $\mathrm{CO}_{2}$ avoided cost for applied CCS technology (supercritical, ultra-supercritical, integrated gasification combined cycle (IGCC), oxy-combustion, natural gas combined cycle (NGCC)) at power generation on economic aspects [26].

On the other hand, the economic evaluation of $\mathrm{CCU}$ focused on sales profit from selling $\mathrm{CO}_{2}$ compounds produced from applying CCU technology or on the life cycle assessment (LCA) [27]. One analyzed a manufacturing technology of high-valued compounds, sodium bicarbonate $\left(\mathrm{NaHCO}_{3}\right)$, through carbon dioxide carbonization, and the result of the internal rate of return for 20 years was $67.2 \%$ [28]. Techno-economic assessment of $\mathrm{CO}_{2}$ utilization was studied by applying LCA of the Canadian emerald energy from a waste facility [29]. LCA conducted for a comprehensive analysis of the climate change mitigation potential of $\mathrm{CCU}$, in applying fields such as fertilizer process [30], $\mathrm{CO}_{2}$-based polymers used as raw materials for plastics [31], chemical industry [32], and electrocatalytic conversion of $\mathrm{CO}_{2}$ into commercially-valued products, including carbon monoxide, methane, and methanol [33-35].

Most CCS economic evaluation of power generation uses LCOE and $\mathrm{CO}_{2}$ avoided cost, with the CCS technology by applying the energy penalty when constructing the power generation plant [36,37]. As mentioned previously, $\mathrm{CCU}$ economic evaluation focuses on the sales revenue of the resulting $\mathrm{CO}_{2}$ compounds from the technology $[29,38,39]$. LCOE represents the average revenue per unit of electricity generated that would be required to recover the costs of building and operating a generating plant during an assumed financial life and duty cycle, $\mathrm{CO}_{2}$ captured cost is calculated by comparing a capture plant to any reference plant, and $\mathrm{CO}_{2}$ avoid cost is derived from the equalization of the net present values of costs of the power plant with and without CCUS technology [40].

Based on the operating data and input cost of a $40 \mathrm{tCO}_{2} /$ day (2 megawatt (MW)) class CCU pilot plant at a coal-fired power plant, the scaled-up $400 \mathrm{tCO}_{2} /$ day $(20 \mathrm{MW})$ class $\mathrm{CCU}$ plant at $500 \mathrm{MW}$ coal-fired power plant was economically analyzed by applying the LCOE and $\mathrm{CO}_{2}$ avoided cost, considering the energy penalty. Moreover, the CCU technology in this study, utilizing the resulting compounds as construction ingredients, has insufficient economic evaluation and comparative studies according to applied technology on the economic evaluation results $[19,41]$. Here, we have calculated the LCOE and $\mathrm{CO}_{2}$ avoided cost for mineral carbonation, resulting in $26 \mathrm{USD} / \mathrm{MWh}$ and $64 \mathrm{USD} / \mathrm{tCO}_{2}$ each, and conducted comparative studies with other CCS and CCU technologies, which were higher cost for each factor.

To remind, this paper is structured as follows: Section 2 introduces the methods and technology of applied examination, with the detailed explanation of the components and the process; Section 3 gives detailed information on the experiment results with the analysis of $\mathrm{LCOE}$ and $\mathrm{CO}_{2}$ avoided cost; Section 4 shows the comparison of the economic analysis between the applied technology in this study and other CCU technologies, and also include sensitivity analysis; Section 5 addresses the conclusion on the applied CCU technology.

The following subjects were considered to increase the accuracy of this research, and a comparative analysis was conducted between the resulting economic outcomes and other CCS or CCU references.

1. Considering the energy penalties resulting from the CCU plant at a $500 \mathrm{MW}$ coal-fired power plant.

2. Application of the actual operational data of a $40 \mathrm{tCO}_{2} /$ day $(2 \mathrm{MW})$ class pilot plant installed at a $500 \mathrm{MW}$ coal-fired power plant. 
3. Application of the actual operational data of the captured $\mathrm{CO}_{2}$ amount collected through a $40 \mathrm{tCO}_{2} /$ day $(2 \mathrm{MW})$ class continuous-capture-process.

4. For the $400 \mathrm{tCO}_{2}$ /day (20 MW class) CCU plant installed at a $500 \mathrm{MW}$ coal-fired power plant that manages the economic evaluation, apply the estimated price of equipment based on the actual preliminary design.

5. By applying the levelized cost of energy analysis (LCOE), compare the " $\mathrm{CO}_{2}$ avoided cost" and " $\mathrm{CO}_{2}$ captured cost" in similar businesses.

- $\quad$ LCOE $=\Sigma(($ Investment cost $t+$ Operation maintenance cost $t+$ Fuel cost $t+$ Power plant abolition cost $\left.\left.{ }_{t}\right) \times(1+\mathrm{r})^{-t}\right) /\left(\Sigma \mathrm{t}\left(\right.\right.$ Power generation $\left.\left.{ }_{t} \times(1+\mathrm{r})^{-t}\right)\right)$

- $\mathrm{CO}_{2}$ capture cost $\left[\mathrm{USD} / \mathrm{tCO}_{2}\right]=(\mathrm{LCOE})_{\mathrm{CCS}}-(\mathrm{LCOE})_{\mathrm{ref}} /\left(\mathrm{tCO}_{2} / \mathrm{MWh}\right)_{\text {captured }}$

- $\mathrm{CO}_{2}$ avoid cost $\left[\mathrm{USD} / \mathrm{tCO} \mathrm{CO}_{2}\right]=(\mathrm{LCOE})_{\mathrm{CCS}}-(\mathrm{LCOE})_{\mathrm{ref}} /\left(\mathrm{tCO}_{2} / \mathrm{MWh}\right)_{\mathrm{CCS}}$

\section{Materials and Methods}

\subsection{Applied Technology}

Mineral carbonation process can effectively utilize the industrial $\mathrm{CO}_{2}$ emissions to form various products and carbonate precipitates, as it is a thermodynamically favorable reaction. The mineral carbonation using alkaline solid wastes has merits of low feedstock cost and availability near the source of $\mathrm{CO}_{2}$ [27]. The utilization process for this study, $\mathrm{CCU}$ of mineral carbonation technology, produces construction ingredients from converting the $\mathrm{CO}_{2}$-captured compounds to $\mathrm{CaCO}_{3}$ through the direct reaction of $\mathrm{CO}_{2}$ in the flue gas at the coal-fired power plant.

This technology operates a $40 \mathrm{tCO}_{2} /$ day $(2 \mathrm{MW}$ ) class CCU pilot plant at a coal-fired power plant in Korea from November 2017. Inserted partial flue gas, emitted from the power plant duct into the CCU plant, produce $\mathrm{CO}_{2}$-captured compounds $\left(\mathrm{CaCO}_{3}\right)$, and unreacted $\mathrm{CO}_{2}$ returns to the power plant duct to maintain the $\mathrm{CO}_{2}$ concentration below $1 \%$ in the atmosphere. The applied technology and main equipment configuration are as follows (Figure 1, Table 1):

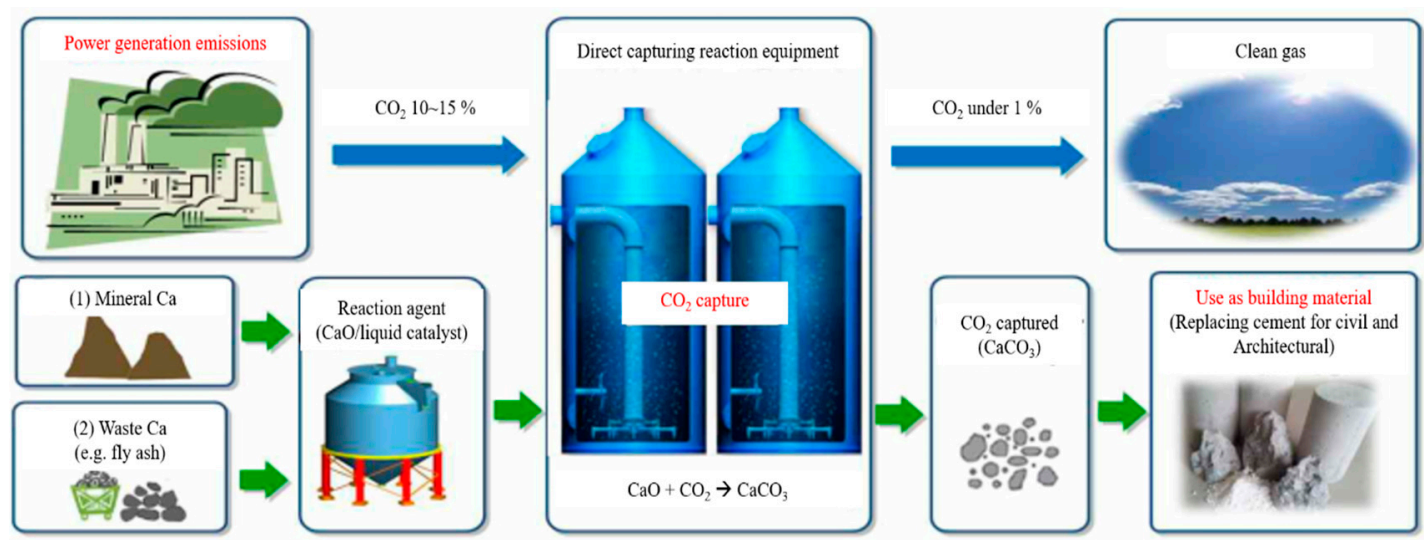

Figure 1. Principle of carbon capture and utilization (CCU) technology applied in this study.

Table 1. $40 \mathrm{tCO}_{2} /$ day class CCU pilot plant components.

\begin{tabular}{cc}
\hline Classification & Components \\
\hline Facility name & Direct $\mathrm{CO}_{2}$ capture-process pilot plant \\
\hline Facility capacity & $7000 \mathrm{Nm}^{3} / \mathrm{h}$ \\
\hline $\mathrm{CO}_{2}$ removal amount & 40 ton/day \\
\hline Monitored $\mathrm{CO}_{2}$ removal amount & 25.94 ton/day \\
\hline $\mathrm{CaCO}_{3}$ production & 61.80 ton/day \\
\hline
\end{tabular}


Table 1. Cont.

\begin{tabular}{|c|c|c|}
\hline Classification & & Components \\
\hline $\begin{array}{l}\text { Measured } \mathrm{CO}_{2} \text { content in } \\
\mathrm{CaCO}_{3} \text { production }\end{array}$ & & $38.29 \%$ (TGA analysis) \\
\hline $\begin{array}{l}\text { Measured electric power } \\
\text { consumption (Real data) }\end{array}$ & & $0.8 \mathrm{MW}$ \\
\hline \multirow{3}{*}{ Main equipment } & Agent supply system & $\begin{array}{l}\text { After storing mineral powder and slag powder, provide } \\
\text { a quantitative influx into the reaction agent dissolved } \\
\text { tank, and dissolve it for ( } 30-40 \text { ) min. } \rightarrow \text { Mix ( } 30-40) \text { min } \\
\text { for all of the CaO to react } \rightarrow \text { Transport steam and dust } \\
\text { generated from the reaction agent reacting process to the } \\
\text { desorption liquid storage tank (no wastewater } \\
\text { generation). }\end{array}$ \\
\hline & $\begin{array}{c}\mathrm{CO}_{2} \text { removal process } \\
\text { system }\end{array}$ & $\begin{array}{l}\text { The first removal of } \mathrm{CO}_{2} \text { through reacting agent and } \\
\text { gas-liquid contact in the first reaction tower. } \rightarrow \\
\text { Discharge after removing residual } \mathrm{CO}_{2} \text { with the reacting } \\
\text { agent in the secondary reaction tower. } \rightarrow \text { Supplement } \\
\text { from the secondary reaction tower by the } \mathrm{CO}_{2} \text {-captured } \\
\text { transfer pump of the first reaction tower when the } \\
\text { chemical agents in the first reaction tower reach below } \\
\text { pH } 8.5 \text {, while reacting with } \mathrm{CO}_{2} \text { in the emission gas. } \\
\text { Real-time monitoring and analysis of } \mathrm{CO}_{2} \text { concentration } \\
\text { by } \mathrm{CO}_{2} \text { analyzer installed before and after the reaction } \\
\text { tower duct. } \\
\text { Real-time monitoring and control from the main } \\
\text { computer by measuring the temperature, flow rate, flux, } \\
\text { and flow pressure. }\end{array}$ \\
\hline & $\begin{array}{c}\text { Captured } \mathrm{CO}_{2} \text { treatment } \\
\text { system }\end{array}$ & $\begin{array}{l}\text { Some of the generated } \mathrm{CO}_{2} \text {-captured compounds are } \\
\text { used as the ingredient of construction materials (bricks, } \\
\text { cements block, and so forth) after the dehydrating } \\
\text { process in a dehydrator. The remaining undehydrated } \\
\mathrm{CO}_{2} \text {-captured compounds are used as reagent, such as a } \\
\text { desulfurization agent. } \rightarrow \text { Effluent from the dehydration } \\
\text { process is used as the full chemical reagent } \\
\text { manufacturing water, and the deficiency is } \\
\text { supplemented with water. } \rightarrow \text { The dehydrated cake is } \\
\text { placed in a ton bag for a certain time, and then taken out. }\end{array}$ \\
\hline
\end{tabular}

\subsection{Applied Scale and Process}

The applicable field scale for this study, a $400 \mathrm{tCO}_{2}$ /day class CCU plant, can be designed by knowing the actual amount of reduced $\mathrm{CO}_{2}$ from the operating $40 \mathrm{tCO}_{2} /$ day class CCU pilot plant, and modifying the operational problems from the pilot plant. Based on this scaled-up field scale plant, the economic evaluation was conducted for a $400 \mathrm{tCO}_{2}$ /day class CCU plant. The scaled-up preliminary design of the $400 \mathrm{tCO}_{2}$ /day class CCU plant is as follows (Table 2, Figure 2):

Table 2. Preliminary design outline of the $400 \mathrm{tCO}_{2}$ /day class CCU plant.

\begin{tabular}{|c|c|c|}
\hline \multicolumn{2}{|c|}{ Classification } & Project Outline \\
\hline \multicolumn{2}{|c|}{ Project name } & $\begin{array}{l}\text { Preliminary design of a demonstration plant of the } 400 \mathrm{tCO}_{2} / \text { day } \\
\text { class direct } \mathrm{CO}_{2} \text { capture-removal process }\end{array}$ \\
\hline \multicolumn{2}{|c|}{ Location } & Local power plant, cement or steel manufacturing plant \\
\hline \multicolumn{2}{|c|}{ Facility capacity } & $60,000 \mathrm{Nm}^{3} / \mathrm{h}$ \\
\hline \multicolumn{2}{|c|}{$\mathrm{CO}_{2}$ removal amount } & $400 \mathrm{tCO}_{2} /$ day \\
\hline \multirow[b]{2}{*}{ Task range } & Mechanical field & $\begin{array}{l}\text { Preliminary design of machinery, such as ingredients and } \\
\text { chemical reagent supply facility, } \mathrm{CO}_{2} \text { removal reacting facility, } \\
\mathrm{CO}_{2} \text {-captured treatment facility, and other process facilities. }\end{array}$ \\
\hline & $\begin{array}{l}\text { Electric measurement and } \\
\text { control field }\end{array}$ & $\begin{array}{l}\text { Preliminary design of electric measurement and control field, } \\
\text { such as motor control center (MCC) module, electric panel, and } \\
\text { process measuring instrument. }\end{array}$ \\
\hline
\end{tabular}




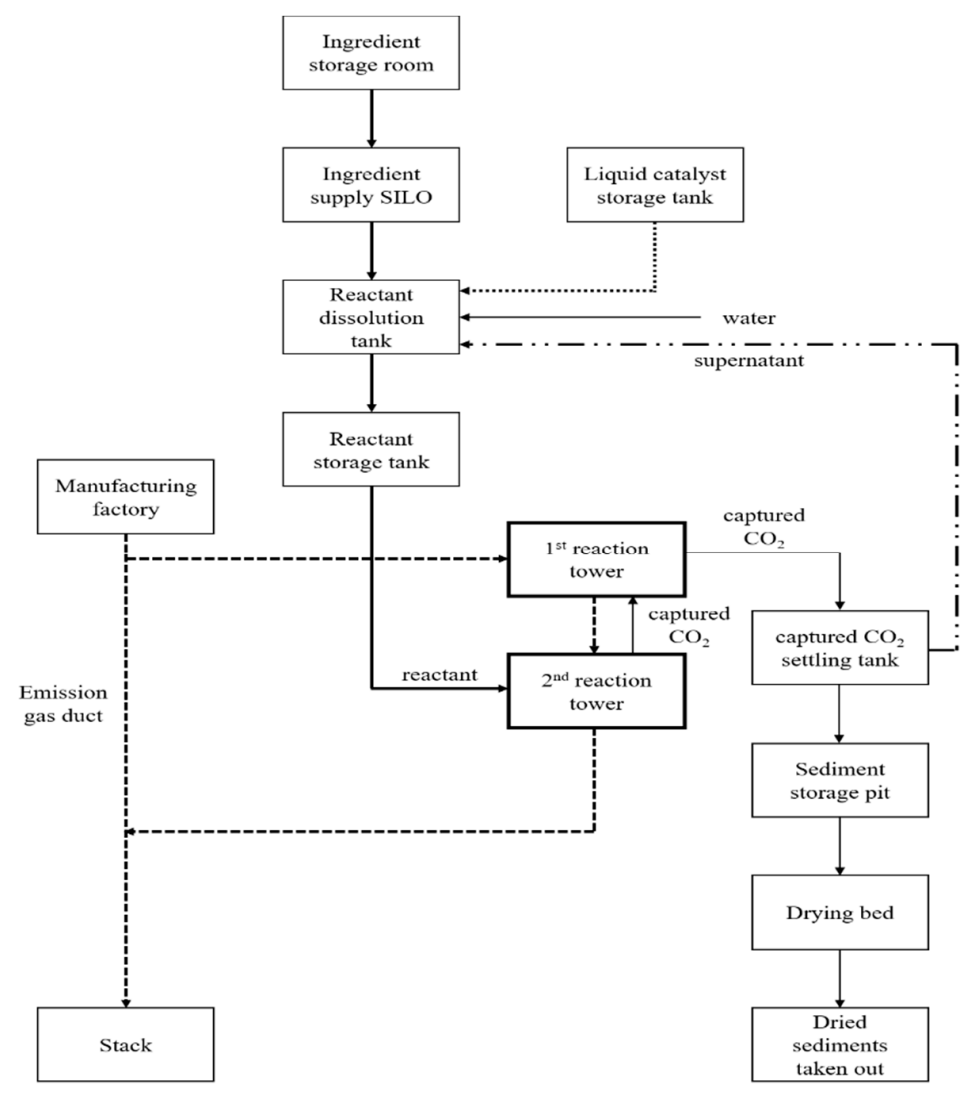

Figure 2. Process flow chart of the $400 \mathrm{tCO}_{2} /$ day class direct $\mathrm{CO}_{2}$ capture-process.

Therefore, the applied facility and process of this study are as follows (Table 3):

Table 3. Description of the $400 \mathrm{tCO}_{2}$ /day class CCU plant.

\begin{tabular}{|c|c|c|}
\hline \multicolumn{2}{|c|}{ Classification } & Contents \\
\hline \multicolumn{2}{|c|}{ Facility capacity } & $60,000 \mathrm{Nm}^{3} / \mathrm{h}\left(15,000 \mathrm{Nm}^{3} / \mathrm{h} \times 4\right.$ series $)$ \\
\hline \multicolumn{2}{|c|}{ Operating time } & 24 h/day, 350 days \\
\hline \multicolumn{2}{|c|}{ Construction period } & 36 months \\
\hline \multirow[t]{4}{*}{ Treatment process } & $\begin{array}{l}\text { Chemical reagent supply } \\
\text { facility }\end{array}$ & $\begin{array}{l}\text { Ingredient storage room/ingredient input } \\
\text { hopper/ingredient transfer conveyor/ingredient supply } \\
\text { conveyor/ingredient supply SILO/ingredient input } \\
\text { conveyor/reactant dissolution tank/reactant transfer } \\
\text { pump/reactant storage tank/reactant supply pump/liquid } \\
\text { catalyst storage tank/liquid catalyst supply pump }\end{array}$ \\
\hline & $\mathrm{CO}_{2}$ removal reacting facility & $\begin{array}{l}\text { Emission gas cooling tower/cooling tower circulation } \\
\text { pump/emission gas pressurized blower/reaction } \\
\text { tower/reaction tower circulation pump/reaction tower } \\
\text { transfer pump of } \mathrm{CO}_{2} \text {-captured }\end{array}$ \\
\hline & $\begin{array}{l}\mathrm{CO}_{2} \text {-captured treatment } \\
\text { facility }\end{array}$ & $\begin{array}{l}\mathrm{CO}_{2} \text {-captured settling tank/sediment collector/sediment } \\
\text { outlet/sediment transfer pump/supernatant treating } \\
\text { tank/supernatant reuse-pump/sediment storage } \\
\text { pit/drying bed }\end{array}$ \\
\hline & Other facility & $\begin{array}{l}\text { Supernatant storage tank/water storage tank/process } \\
\text { liquid supply pump/air compressor/pit pump/bottom } \\
\text { drain pump }\end{array}$ \\
\hline
\end{tabular}


Table 3. Cont

\begin{tabular}{|c|c|}
\hline Classification & Contents \\
\hline $\mathrm{CO}_{2}$-captured compounds treatment plan & $\begin{array}{l}\text { Precipitate the } \mathrm{CO}_{2} \text {-captured in settling tank, } \\
\text { supernatant overflows into the supernatant treating tank, } \\
\text { and reuse it as process liquid. The residual sediment is } \\
\text { sent to the sediment storage pit, and then stacked on the } \\
\text { drying bed by excavator. After the sediments are dried, } \\
\text { they are taken out to supply the required site. }\end{array}$ \\
\hline Rain water and domestic wastewater treatment plan & $\begin{array}{l}\text { Connected treatment of rain water through rain water } \\
\text { pipeline into the manufacturing plant rainwater pipeline } \\
\text { Connected treatment of domestic wastewater through } \\
\text { wastewater pipeline into the manufacturing plant } \\
\text { wastewater pipeline. }\end{array}$ \\
\hline Emission gas capture method & $\begin{array}{l}\text { Portion of emission gas is captured from the emission } \\
\text { gas transfer duct generated during the carbon fuel } \\
\text { combustion process. }\end{array}$ \\
\hline
\end{tabular}

\section{Results}

\subsection{Cost Calculation of a 500 MW Coal-Fired Power Plant}

To conduct the economic evaluation by demonstration plant of the $400 \mathrm{tCO}_{2} /$ day class CCU plant, an economic evaluation of a $500 \mathrm{MW}$ coal-fired power plant was first conducted (Table 4). The applying assumptions are based on the applied data of IEA economic evaluation, and the information provided by the actual domestic power generation companies.

Table 4. Estimated cost of the $500 \mathrm{MW}$ coal-fired power plant.

\begin{tabular}{|c|c|c|c|}
\hline $\begin{array}{l}500 \text { MW Coal-Fired Thermal } \\
\text { Power Plant }\end{array}$ & Applied Value & Unit & Note \\
\hline Discount rate & 7 & $\%$ & $\begin{array}{c}\text { Assumption } \\
\text { (IEA data for reference) }\end{array}$ \\
\hline Load factor & 85 & $\%$ & $\begin{array}{l}3 \text { year average of } \\
\text { Domestic power plant }\end{array}$ \\
\hline Plant lifetime & 25 & Year & $\begin{array}{l}\text { Assumption } \\
\text { (IEA data for reference) }\end{array}$ \\
\hline Capacity & 500 & MW & Assumption \\
\hline Annual generated electricity & $3,570,000$ & MWh/year & $500 \mathrm{MW} \times 85 \% \times 350$ day $\times 24 \mathrm{~h}$ \\
\hline Thermal efficiency & 40 & $\%$ & $\begin{array}{c}\text { Assumption } \\
\text { (IEA data for reference) }\end{array}$ \\
\hline Equipment cost & 875 & $\mathrm{USD} / \mathrm{kW}$ & $\begin{array}{c}\text { Assumption } \\
\text { (construction cost of } \\
\text { domestic power plant) }\end{array}$ \\
\hline Annual fixed cost & 4 & Construction $\cos t \%$ & $\begin{array}{c}\text { Assumption } \\
\text { (IEA data for reference) }\end{array}$ \\
\hline Annual variable cost & 0.5 & Construction $\cos t \%$ & $\begin{array}{c}\text { Assumption } \\
\text { (IEA data for reference) }\end{array}$ \\
\hline Fuel cost & 0.83 & USD/GJ & $\begin{array}{c}\text { Assumption } \\
\text { (IEA data for reference) }\end{array}$ \\
\hline Capex & 437.5 & M USD & $500 \mathrm{MW} \times 875 \mathrm{USD} / \mathrm{kW}$ \\
\hline Annual operating \& maintain cost & 19.7 & M USD/year & $4.5 \% \times 437.5 \mathrm{M}$ USD \\
\hline Annual fuel cost & 26.8 & M USD/year & $\begin{array}{c}(3,570,000 \mathrm{MWh} / 40 \%) \times 3.6 \mathrm{GJ} / \mathrm{MWh} \\
\times 0.83 \mathrm{USD} / \mathrm{GJ}\end{array}$ \\
\hline Capex (present value (PV) & 395.7 & M USD & $\begin{array}{c}3 \text { year (1st year } 10 \% \text {, 2nd year } 30 \% \text {, } \\
\text { 3rd year } 60 \% \text { ) }\end{array}$ \\
\hline Opex $(\mathrm{PV})$ & 472.9 & M USD & Opex for 25 year \\
\hline $\begin{array}{l}\text { Generated electricity } \\
\text { (PV) }\end{array}$ & $36,337,926$ & MWh & Generated electricity for 25 year \\
\hline
\end{tabular}




\subsection{Cost Calculation for the $400 \mathrm{tCO}_{2} /$ day Class CCU Plant}

The additional capex for installing the $400 \mathrm{tCO}_{2}$ /day class CCU plant at the $500 \mathrm{MW}$ coal-fired power plant is based on the 2018 price level, which was also applied for the preliminary design of the $400 \mathrm{tCO}_{2}$ /day class CCU plant. The information on additional construction costs is as follows (Table 5):

Table 5. Construction cost for the demonstration plant of the $400 \mathrm{tCO}_{2} /$ day class CCU plant.

\begin{tabular}{cccc}
\hline Construction Cost & Applied Value & Unit & Note \\
\hline Mechanical construction & 6.0 & M USD & Preliminary design report \\
Electric construction & 1.6 & M USD & Preliminary design report \\
Civil/architectural construction & 10.2 & M USD & Preliminary design report \\
\hline Total construction cost & 17.8 & M USD & Preliminary design report \\
\hline
\end{tabular}

The additional opex for installing the $400 \mathrm{tCO}_{2}$ /day class CCU plant at the $500 \mathrm{MW}$ coal-fired power plant is based on the 2018 electric and water cost, which was also applied for the preliminary design of the $400 \mathrm{tCO}_{2}$ /day class $\mathrm{CCU}$ plant. The information on additional operating costs is as follows (Table 6):

Table 6. Annual opex for the $400 \mathrm{tCO}_{2}$ /day class CCU plant.

\begin{tabular}{|c|c|c|c|c|c|}
\hline Classification & Item & $\begin{array}{l}\text { Price } \\
\text { Unit }\end{array}$ & Unit & Usage & $\begin{array}{l}\text { Total Amount } \\
\text { (USD) }\end{array}$ \\
\hline Labor costs & Operator & 2500 & $\begin{array}{l}\text { USD/man } \\
\text { month }\end{array}$ & $\begin{array}{l}32 \text { people, } \\
12 \text { months }\end{array}$ & 960,000 \\
\hline \multirow{2}{*}{ Electric power cost } & Contract power & 8.18 & USD/kw/month & 60,000 & 490,500 \\
\hline & $\begin{array}{l}\text { Electric power } \\
\text { consumption }\end{array}$ & 0.075 & $\mathrm{USD} / \mathrm{kw} \times \mathrm{h}$ & $22,400,880$ & $1,689,361$ \\
\hline \multicolumn{2}{|c|}{ Sub Total } & & & & $2,179,861$ \\
\hline \multirow{3}{*}{ Reagent cost } & Calcium hydroxide & 75 & USD/ton & 0 & 0 \\
\hline & Fly ash & 4.17 & USD/ton & 363,672 & $1,515,300$ \\
\hline & Liquid catalyst & 416.7 & USD/ton & 763 & 318,000 \\
\hline \multicolumn{2}{|c|}{ Sub Total } & & & & $1,833,300$ \\
\hline \multirow{2}{*}{ Water cost } & Basic fee & 49.2 & USD/ton/month & 12 & 590 \\
\hline & Usage fee & 0.78 & $\mathrm{USD} / \mathrm{m}^{3}$ & 385,200 & 301,740 \\
\hline \multicolumn{2}{|c|}{ Sub Total } & & & & 302,330 \\
\hline \multicolumn{2}{|c|}{ Total annual operating cost } & & & & $5,275,491$ \\
\hline
\end{tabular}

\subsection{Economic Evaluation Method and Cost Calculation of the CCU Plant}

3.3.1. Economic Evaluation Method for the 500 MW Coal-Fired Power Plant Including the $400 \mathrm{tCO}_{2}$ /day Class CCU Plant

Based on Sections 3.1 and 3.2, the following considerations are needed to calculate the cost of the $500 \mathrm{MW}$ coal-fired power plant including a demonstration plant with a $400 \mathrm{tCO}_{2} /$ day class CCU plant.

- Energy penalty caused by the installation of a CCU facility

- Increase in the construction cost according to the increased facility capacity by the energy penalty

First, to calculate the energy penalty by the installation of a CCU plant, the actual measured electric power consumption of the $40 \mathrm{tCO}_{2}$ /day class $\mathrm{CCU}$ pilot plant was applied. The electric power consumption per hour of the $40 \mathrm{tCO}_{2}$ /day class CCU pilot plant was $0.8 \mathrm{MW}$. Accordingly, the power consumption for the $400 \mathrm{tCO}_{2}$ /day class CCU plant was analyzed to consume $4 \mathrm{MW}$ power by applying the "6-10 power rule." Approximate costs can be obtained if the cost of a similar item of different size or capacity is known. The "6-10 power rule," also called 0.6 rule or six tenth rule, is used for scale-up 
of the capacity-cost when analyzing the plant economics. This rule has its origins in the relationship between the increase in equipment cost $(C)$ and the increase in capacity $(V)$ given by $C_{1} / C_{2}=\left(V_{1} / V_{2}\right)^{\alpha}$, where $\alpha$ denotes the scale coefficient. The value of $\alpha=0.6$ refers to equipment such as tanks and pipes which give significant economies of scale [42]. The electric power consumption for the basic design of the $400 \mathrm{tCO}_{2} /$ day class CCU plant was 3.1 MW. The "6-10 power rule" was applied to the relationship between the capacity and the electric power consumption at the $400 \mathrm{tCO}_{2} /$ day class CCU plant and the electric power consumption for the basic design. In this regard, the cost analysis was conducted by applying $4 \mathrm{MW}$, a conservative energy penalty.

Therefore, to secure the sufficient capacity of $500 \mathrm{MW}$ coal-fired power plants, it should be designed as $504 \mathrm{MW}$ in consideration of the energy penalty, which is calculated to be $(504-500) / 504 \times$ $100=0.8 \%$.

Additional cost is incurred, as the installation of a $504 \mathrm{MW}$ coal-fired power plant increases the power generation capacity owing to the energy penalty. The additional cost was recalculated according to the "6-10 power rule," which is used for scale-up of the capacity-cost in economic evaluation.

\subsubsection{Cost Calculation of the $500 \mathrm{MW}$ Coal-Fired Power Plant Including $400 \mathrm{tCO}_{2} /$ day Class} CCU Plant

The cost of the $500 \mathrm{MW}$ coal-fired power plant including $400 \mathrm{tCO}_{2}$ /day class CCU plant is presented in Table 7 [43]. Further detailed data can be found in Table S1.

Table 7. Cost of the $500 \mathrm{MW}$ coal-fired power plant with $400 \mathrm{tCO}_{2} /$ day class CCU plant.

\begin{tabular}{|c|c|c|c|}
\hline $\begin{array}{l}500 \mathrm{MW}+\text { CCU Coal-Fired } \\
\text { Power Plant }\end{array}$ & Applied Value & Unit & Note \\
\hline Discount rate & 7 & $\%$ & Assumption (see IEA data) \\
\hline Load factor & 85 & $\%$ & $\begin{array}{c}\text { Application of } 3 \text { year averagefor domestic } \\
\text { power companies }\end{array}$ \\
\hline Plant lifetime & 25 & year & Assumption (see IEA data) \\
\hline Energy penalty & 0.8 & $\%$ & Calculation form 3.3 \\
\hline Capacity (with CCU) & 504 & MW & Calculation form 3.3 \\
\hline CCU additional capacity & 4 & MW & Calculation form 3.3 \\
\hline Net capacity & 500 & MW & - \\
\hline Annual generated electricity & $3,598,560$ & MWh/year & $504 \mathrm{MW} \times 85 \% \times 350$ days $\times 24 \mathrm{~h}$ \\
\hline Thermal efficiency & 40 & $\%$ & Assumption (see IEA data) \\
\hline Capital expenditure (CAPEX) & 875 & $\mathrm{USD} / \mathrm{kw}$ & Assumption [43] \\
\hline $\begin{array}{l}\text { Annual fixed operating } \\
\text { expenditure (OPEX) }\end{array}$ & 4 & Construction cost $\%$ & Assumption (see IEA data) \\
\hline Annual variable OPEX & 0.5 & Construction cost $\%$ & Assumption (see IEA data) \\
\hline Fuel cost & 0.83 & USD/GJ & Assumption (see IEA data) \\
\hline CAPEX & 439.95 & M USD & $437.5 \mathrm{M}$ USD $\times\left((504 / 500)^{\wedge} 0.7\right)$ \\
\hline Annual OPEX & 19.80 & M USD/year & $4.5 \% \times 439.95 \mathrm{M}$ USD \\
\hline Annual fuel cost & 27.00 & M USD/year & $\begin{array}{c}3,598,860 \mathrm{MWh} / 40 \% \times 3.6 \mathrm{GJ} / \mathrm{MWh} \times \\
\mathrm{USD} / \mathrm{GJ}\end{array}$ \\
\hline Annual emitted $\mathrm{CO}_{2}$ & $3,400,000$ & $\mathrm{tCO}_{2} /$ year & $\begin{array}{l}\text { Actual data of } 500 \mathrm{MW} \text { domestic } \\
\text { coal-fired thermal power plant }\end{array}$ \\
\hline $\begin{array}{l}\text { Levelized cost of energy } \\
\text { analysis (LCOE) }\end{array}$ & 23.90 & USD/MWh & Calculation \\
\hline Only CCU CAPEX & 17.75 & M USD & $\begin{array}{l}\text { Amount statement of the } \mathrm{CO}_{2} \text { direct } \\
\text { capture removal process }\left(400 \mathrm{tCO}_{2} / \text { day }\right)\end{array}$ \\
\hline Only CCU OPEX & 5.25 & M USD/year & $\begin{array}{l}\text { Only cost applied among construction } \\
\text { design report of the direct } \mathrm{CO}_{2} \text { capture } \\
\text { removal process }\left(400 \mathrm{t} \mathrm{CO}_{2} / \text { day }\right)\end{array}$ \\
\hline CAPEX including CCU (PV) & $413,916,667$ & USD & $\begin{array}{c}3 \text { year (10\% for first year, } 30 \% \text { for second } \\
\text { year, } 60 \% \text { for third year) }\end{array}$ \\
\hline OPEX including CCU (PV) & $537,750,000$ & USD & $\begin{array}{c}\text { Including } 25 \text { year of operating and } \\
\text { disposal costs }\end{array}$ \\
\hline Generated electricity(PV) & $36,328,630$ & MWh & Generated electricity for 25 years \\
\hline
\end{tabular}




\subsection{Calculation of $\mathrm{CO}_{2}$ Captured and Avoided Cost}

\subsection{1. $\mathrm{CO}_{2}$ Captured Efficiency and Utilization Rate}

The captured efficiency was calculated based on the actual data of a currently running $40 \mathrm{tCO}_{2} /$ day class CCU pilot plant. The utilization rate was calculated through this captured efficiency. The following data is measured data at the site of the $40 \mathrm{tCO}_{2}$ /day class CCU pilot plant, and the continuously measured data for more than $20 \mathrm{~h}$ in normal operation was applied. The measured data utilized the real-time continuously measured on-site data of flow rate, and $\mathrm{CO}_{2}$ concentration in the inlet and outlet. The following is the monitoring results from the real-time measuring instrument along the time sequence for every hour from 05/29 14:00 to 05/30 12:00 (Figures 3 and 4).

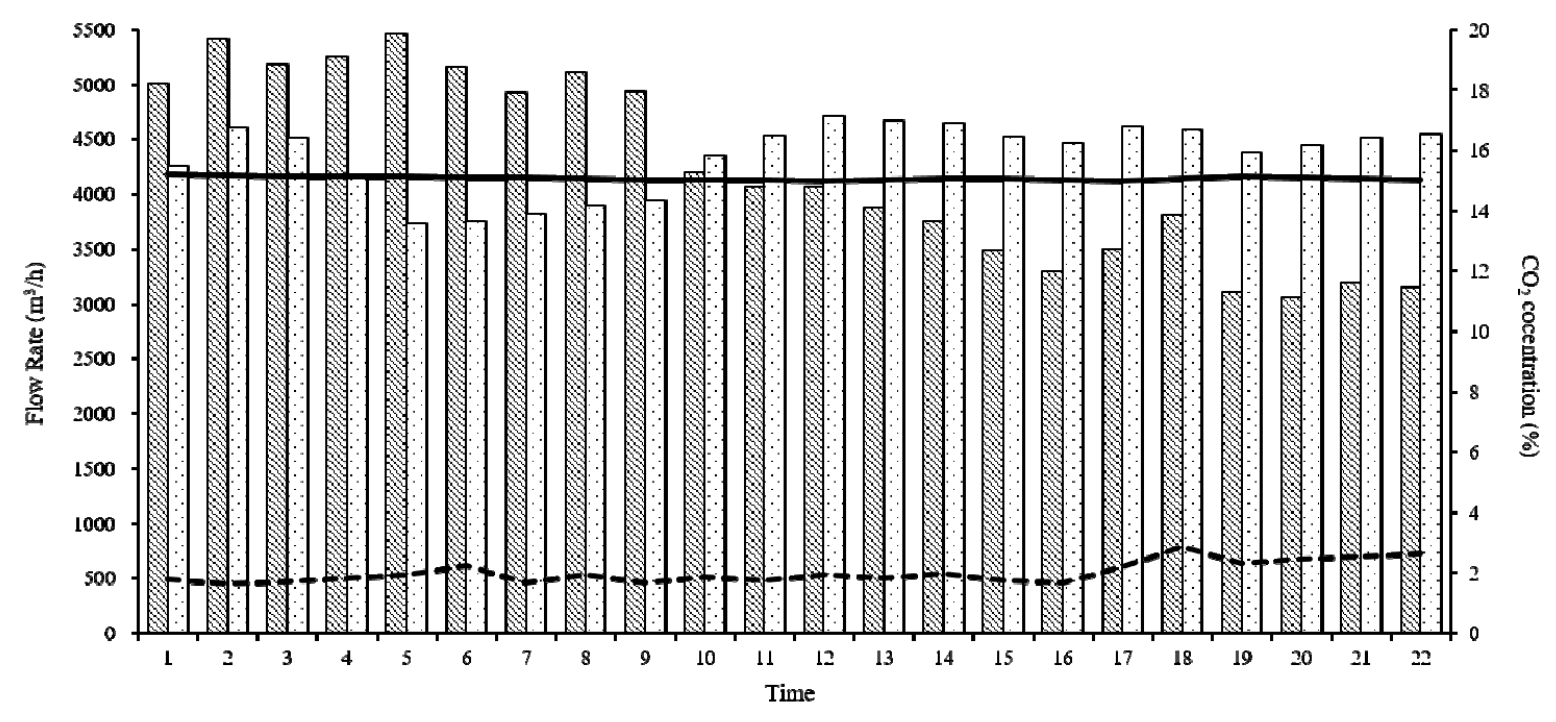

Figure 3. Monitoring results from the real-time measuring instrument.

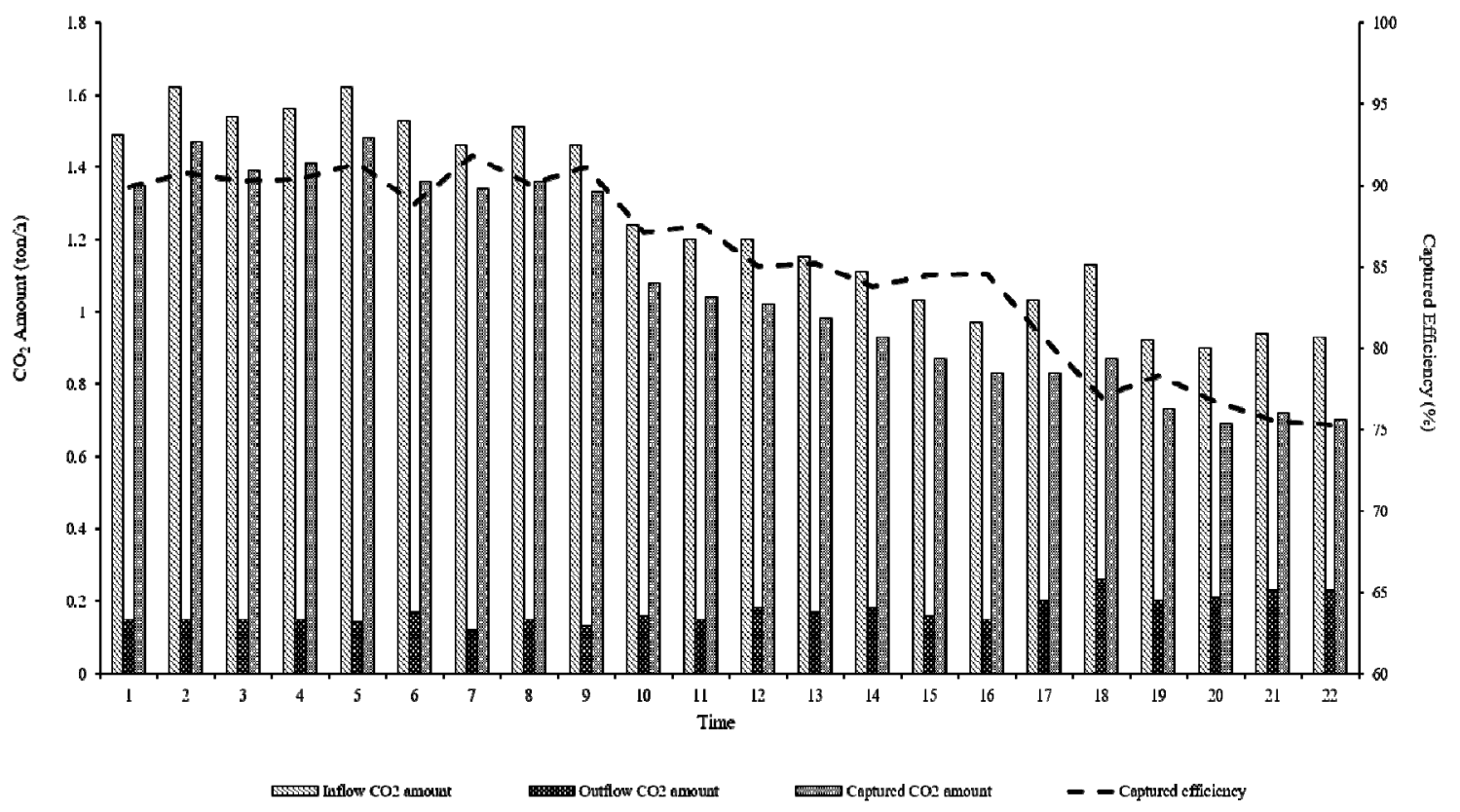

Figure 4. Captured $\mathrm{CO}_{2}$ amount and captured efficiency through monitoring results.

To calculate the utilization rate of the CCU plant, it is necessary to convert the power generating capacity of the $400 \mathrm{tCO}_{2}$ /day class CCU plant. Accordingly, by applying the actual data from a domestic 
coal-fired power plant, the capacity of the $\mathrm{CCU}$ plant was converted based on the captured $\mathrm{CO}_{2}$ amount that could be treated based on the amount of greenhouse gas emissions at the $500 \mathrm{MW}$ coal-fired power plant. A domestic coal-fired power plant emits $6800 \mathrm{tCO}_{2}$ per $1 \mathrm{MW}$. Moreover, a $400 \mathrm{tCO}_{2} /$ day class CCU plant captures $\mathrm{CO}_{2}$ of $20 \mathrm{MW}$ power generation capacity. The captured efficiency was $85.71 \%$ and the utilization rate was $4 \%$ for a $400 \mathrm{tCO}_{2} /$ day class CCU plant among the $500 \mathrm{MW}$ coal-fired power plant emitted $\mathrm{CO}_{2}$. As a result, the captured $\mathrm{CO}_{2}$ utilization rate by a $\mathrm{CCU}$ plant was calculated to be $3.43 \%$.

\subsubsection{Calculation of the $\mathrm{CO}_{2}$ Avoided Cost}

The " $\mathrm{CO}_{2}$ avoided" was calculated using the analyzed data from Section 3.4.1. The $\mathrm{CO}_{2}$ avoided is the amount of avoided (reduced) $\mathrm{CO}_{2}$ by operating the $\mathrm{CCU}$ plant. The following are the $\mathrm{CO}_{2}$ avoided value (Table 8):

Table 8. $\mathrm{CO}_{2}$ avoided of the 400 tonCO 2 /day class $\mathrm{CCU}$ plant.

\begin{tabular}{|c|c|c|c|}
\hline $\begin{array}{l}\text { Calculation of } \\
\mathrm{CO}_{2} \text { Avoided }\end{array}$ & $\begin{array}{l}\text { Applied } \\
\text { Value }\end{array}$ & Unit & Note \\
\hline \multicolumn{4}{|c|}{ Coal-fired power plant without CCU } \\
\hline Capacity & 500 & MW & \\
\hline Annual generated electricity & $3,570,000$ & MWh/year & $500 \mathrm{MW} \times 85 \% \times 350$ day $\times 24 \mathrm{~h}$ \\
\hline Annual emitted $\mathrm{CO}_{2}$ & $3,400,000$ & $\mathrm{tCO}_{2} /$ year & $\begin{array}{c}\text { Actual data of } 500 \mathrm{MW} \text { domestic coal-fired thermal } \\
\text { power plant }\end{array}$ \\
\hline $\mathrm{CO}_{2}$ emission factor & 0.9524 & $\mathrm{tCO}_{2} / \mathrm{MWh}$ & $\mathrm{CO}_{2}$ emission/generated electricity \\
\hline \multicolumn{4}{|c|}{ Coal-fired power plant with CCU } \\
\hline Energy penalty & 0.8 & $\%$ & Calculated in Section 3.3. \\
\hline Capacity (with CCU) & 504 & MW & \\
\hline Annual emitted $\mathrm{CO}_{2}$ & $3,598,560$ & MWh/year & $500 \mathrm{MW} \times 85 \% \times 350$ day $\times 24 \mathrm{~h}$ \\
\hline $\mathrm{CO}_{2}$ emission factor & 0.9524 & $\mathrm{tCO}_{2} / \mathrm{MWh}$ & \\
\hline $\begin{array}{l}\mathrm{CO}_{2} \text { captured and } \\
\text { utilization rate }\end{array}$ & 3.43 & $\%$ & $\mathrm{CO}_{2}$ captured efficiency $(85.71 \%) \times(20 \mathrm{MW} / 500 \mathrm{MW})$ \\
\hline $\mathrm{CO}_{2}$ emission & $3,427,200$ & $\mathrm{tCO}_{2} /$ year & Generated electricity $\times \mathrm{CO}_{2}$ emission factor (Korea) \\
\hline $\begin{array}{l}\mathrm{CO}_{2} \text { captured and utilization } \\
\text { amount }\end{array}$ & 117,504 & $\mathrm{tCO}_{2} /$ year & $\mathrm{CO}_{2}$ emission $\times \mathrm{CO}_{2}$ captured and utilization rate \\
\hline $\mathrm{CO}_{2}$ emission without $\mathrm{CCU}$ & $3,400,000$ & $\mathrm{tCO}_{2} /$ year & Actual data of $500 \mathrm{MW}$ domestic coal-fired power plant \\
\hline Net $\mathrm{CO}_{2}$ emission & $3,309,696$ & $\mathrm{tCO}_{2} /$ year & $\mathrm{CO}_{2}$ emission- $\mathrm{CO}_{2}$ capture and utilization amount \\
\hline $\mathrm{CO}_{2}$ avoided & 90,304 & $\mathrm{tCO}_{2} /$ year & $\mathrm{CO}_{2}$ emission without $\mathrm{CCU}$-net $\mathrm{CO}_{2}$ emission \\
\hline
\end{tabular}

As calculated in the above table, the $\mathrm{CO}_{2}$ avoided was calculated to be $90,304 \mathrm{tCO}_{2} /$ year compared to the former coal-fired power plant by the introduction of a $20 \mathrm{MW} \mathrm{CCU}$ plant, which can process $400 \mathrm{tCO}_{2}$ /day (Table 9):

Table 9. $\mathrm{CO}_{2}$ avoided cost and LCOE.

\begin{tabular}{cccc}
\hline Classification & Applied Value & Unit & Note \\
\hline & Coal-fired plant without CCU & \\
Current construction cost & 395.67 & M USD & \\
Current operation cost & 472.92 & M USD & On a 25 year basis \\
LCOE & $36,337,926$ & MWh & On a 25 year basis \\
Current electric power generation cost & 23.90 & USD/MWh & \\
Current construction cost & Coal-fired plant with CCU & \\
Current operation cost & 413.92 & M USD & \\
Current electric power generation cost & 537.75 & M USD & On a 25 year basis \\
LCOE & $36,628,630$ & MWh & On a 25 year basis \\
\hline $\mathrm{CO}_{2}$ avoided cost & 25.98 & USD/MWh & \\
\hline
\end{tabular}




\section{Discussion}

\subsection{Comparative Analysis with Other Studies}

To sum up, the economic analysis results show that when $\mathrm{CO}_{2}$ content is $3.43 \%$ of captured and utilization, the captured and recovery emission is $117,504 \mathrm{tCO}_{2}$ /year, $\mathrm{LCOE}$ as $26 \mathrm{USD} / \mathrm{MWh}$, and $\mathrm{CO}_{2}$ avoided cost as $64 \mathrm{USD} / \mathrm{tCO}_{2}$.

Table 10 compares the economic analysis of this study and other CCS or CCU technology. Different CCS technologies at coal-fired power plants such as IGCC + CCS, NGCC + CCS, PC supercritical, etc., which can capture and utilize $90 \%$ of $\mathrm{CO}_{2}$, as compared to have higher $\mathrm{LCOE}$ and $\mathrm{CO}_{2}$ avoided cost, considering the cost for the processes like $\mathrm{CO}_{2}$ compression, refinement, transport, and storage. Among CCU technologies in Table 10, the Coal-fired power plant (500 MW, 2010, recovery by dry sorbent), Coal-fired power plant (2010, US), and Aluminum production (2013, Norway) were calculated to have smaller $\mathrm{LCOE}$ and $\mathrm{CO}_{2}$ avoided cost than the studied mineral carbonation because they only included the refinement and compression process of $\mathrm{CO}_{2}$ and did not consider the $\mathrm{CO}_{2}$ utilization cost. By comparing with a similar study, Coal powered (UK, $600 \mathrm{MW}$, mineral carbonation), our study resulted to be more economic.

Table 10. Comparison of avoidance cost of $\mathrm{CO}_{2}$ and similar businesses.

\begin{tabular}{|c|c|c|c|c|c|c|}
\hline & nitting Source & $\begin{array}{l}\text { Generated } \\
\text { Emissions } \\
{\left[\mathrm{tCO}_{2} / \text { year }\right]}\end{array}$ & $\begin{array}{c}\mathrm{CO}_{2} \text { Captured } \\
\text { and Utilization } \\
\text { Rate } \\
{[\%]}\end{array}$ & $\begin{array}{l}\text { Captured, } \\
\text { Recovery } \\
\text { Emissions } \\
{\left[\mathrm{tCO}_{2} / \text { year] }\right.}\end{array}$ & $\begin{array}{c}\text { LCOE } \\
\text { [USD/MWh] }\end{array}$ & $\begin{array}{c}\mathrm{CO}_{2} \\
\text { Avoided } \\
\text { Cost } \\
{\left[\mathrm{USD} / \mathrm{tCO}_{2}\right]}\end{array}$ \\
\hline \multicolumn{2}{|c|}{$\begin{array}{l}\text { Coal-fired thermal power plant, } \\
\text { Republic of Korea (mineral } \\
\text { carbonation of this study) }\end{array}$} & $3,427,200$ & 3.43 & $\begin{array}{l}117,504 \\
\text { (Captured } \\
\text { efficiency } \\
85.71 \% \text { ) }\end{array}$ & 26 & 64 \\
\hline \multirow{3}{*}{ CCS } & $\begin{array}{l}\text { IGCC + CCS, US, } \\
2015, \text { FOAK [11] }\end{array}$ & $4,245,600$ & 90 & $3,819,360$ & 141 & 97 \\
\hline & $\begin{array}{l}\text { NGCC + CCS, US, } \\
2015, \text { FOAK [11] }\end{array}$ & $1,971,000$ & 90 & $1,769,520$ & 78 & 89 \\
\hline & $\begin{array}{l}\text { PC supercritical. CCS, } \\
\text { US, 2015, FOAK [11] }\end{array}$ & $4,677,840$ & 90 & $4,204,800$ & $124-133$ & $74-83$ \\
\hline \multirow[t]{4}{*}{$\mathrm{CCU}$} & $\begin{array}{l}\text { Coal-fired power } \\
\text { plant }(500 \mathrm{MW}, 2010, \\
\text { recovery by dry } \\
\text { sorbent) }[20]\end{array}$ & $4,090,625$ & 80 & $3,272,500$ & 32.46 & $\begin{array}{c}\text { Capture cost } \\
28.15\end{array}$ \\
\hline & $\begin{array}{l}\text { Coal-fired power } \\
\text { plant }(2010, \text { US) [9] }\end{array}$ & - & $85-100$ & - & $\begin{array}{l}\text { Included in } \\
\text { avoidance } \\
\text { cost }\end{array}$ & $\begin{array}{c}\text { Capture cost } \\
43-58\end{array}$ \\
\hline & $\begin{array}{c}\text { Aluminum } \\
\text { production } \\
(2013 \text {, Norway) }[21]\end{array}$ & - & - & $\begin{array}{c}\text { Capture rate } \\
\text { of } 85 \%\end{array}$ & - & $\begin{array}{l}\text { Capture cost } \\
80-105\end{array}$ \\
\hline & $\begin{array}{l}\text { Coal powered } \\
\text { (UK, } 600 \mathrm{MW} \text {, mineral } \\
\text { carbonation) [22] }\end{array}$ & $\begin{array}{l}\text { Approx. } \\
4,000,000\end{array}$ & $85 \%$ & $3,400,000$ & - & $86-140$ \\
\hline
\end{tabular}

Additionally, for precise comparison, they should be compared with the same capacity and $\mathrm{CO}_{2}$ captured efficiency. However, this study shows the economic analysis results of a $20 \mathrm{MW} \mathrm{CCU}$ facility, handling $400 \mathrm{tCO}_{2}$ /day based on the operating CCU plant. Therefore, the reliability lowering assumption, such as capacity expansion, and capture amount increase, was not included.

\subsection{Sensitivity Analysis}

The sensitivity of LCOE and $\mathrm{CO}_{2}$ avoided cost, which were results from the economic analysis, was analyzed as the initial conditions changed (Figure 5). The sensitivity of LCOE was analyzed according to the alternation of capital expenditure (CAPEX) and operating expenditure (OPEX) cost and the sensitivity of $\mathrm{CO}_{2}$ avoided cost was analyzed according to the change in $\mathrm{CO}_{2}$ captured 
and utilization rate, and energy penalty (Figure $5 a$ ). Figure $5 b$ illustrates when CAPEX was altered $\pm 10 \%$, LCOE was $\pm 6.55 \%$ altered, and the $\pm 10 \%$ OPEX alternation resulted in $\pm 5.65 \%$ alternation of LCOE. $\pm 10 \%$ change of energy penalty and $\mathrm{CO}_{2}$ captured and utilization rate resulted $\pm 0.71 \%$ and $-9.09 \sim 11.11 \%$ alternation of $\mathrm{CO}_{2}$ avoided cost each. LCOE was most affected by the CAPEX and the OPEX also effected the LCOE as it is linked with CAPEX. $\mathrm{CO}_{2}$ captured and utilization rate affected the $\mathrm{CO}_{2}$ avoided cost the most, showing greater sensitivity than by the effect of energy penalty alternation.
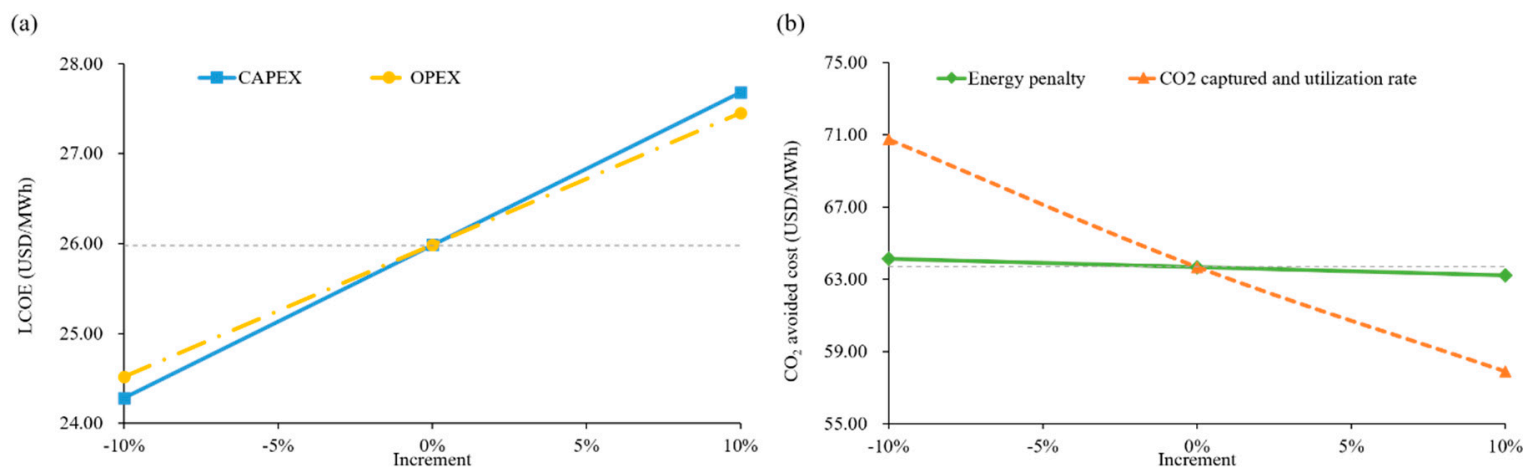

Figure 5. Sensitivity analysis according to the increment. (a) $\mathrm{LCOE} \mathrm{(b)} \mathrm{CO}_{2}$ avoided cost.

The sensitivity analysis represented that the $\mathrm{CO}_{2}$ avoided cost of the mineral carbonation technology in this study, was greatly affected by the $\mathrm{CO}_{2}$ captured and utilization rate; however, owing to the low energy penalty of this study, the energy penalty had little impact.

\section{Conclusions}

Using LCOE and $\mathrm{CO}_{2}$ avoided cost, the economic assessment was conducted for the mineral carbonation $\mathrm{CCU}$ technology at the coal-fired thermal power plant, which produces $\mathrm{CaCO}_{3}$ through direct reaction with $\mathrm{CaO}$ without refinement or compression process for $\mathrm{CO}_{2}$ in the flue gas. In order to increase the accuracy and reliability of this analysis, based on the actual operating data of the $40 \mathrm{tCO} /$ day class CCU pilot plant, the scaled-up $400 \mathrm{tCO}_{2}$ /day CCU plant factors were used. Furthermore, the additionally generated power capacity from the CCU facility energy penalty was also considered for the economic analysis including coal-fired power plant construction and operating cost. The utilization rate for the $\mathrm{CO}_{2}$ capture of the $\mathrm{CCU}$ plant in this study is $3.43 \%$, which represents a lower capacity of CCU compared to similar businesses and the $\mathrm{CO}_{2}$ avoided cost for the $400 \mathrm{tCO}_{2}$ /day class CCU plant applying mineral carbonation technology was $64 \mathrm{USD} / \mathrm{tCO}_{2}$, representing low avoided cost, compared to similar scaled CCS and other CCU plant. However, according to the sensitivity analysis, LCOE was greatly affected by CAPEX, showing $6.55 \%$ variation, and $\mathrm{CO}_{2}$ captured and utilization rate was the biggest effect to cause variation to the $\mathrm{CO}_{2}$ avoided cost. Based on this study, the $\mathrm{CO}_{2}$ avoided cost may become lower by the economy of scale, even if the $\mathrm{CO}_{2}$ treatment capacity of the CCU plant could be extended as much as similar businesses. This suggests that CCU technology by mineral carbonation has an economic advantage in energy penalty, power plant construction, and operating cost over other CCS and CCU with other technology.

Also, this economic analysis is based on the actual operation data of CCU plant and has a relatively small CCU plant capacity compared to other studies. Therefore, there is a limitation that CO2 captured and utilization rate is low. However, with further research, we plan to conduct economic analysis on actual large scaled CCU plant and plan to contribute to commercialization of CCU technology.

Supplementary Materials: The following are available online at http://www.mdpi.com/2071-1050/12/15/6175/s1, Table S1: Economic evaluation of the $500 \mathrm{MW}$ coal-fired power plant installed $400 \mathrm{tCO}_{2}$ /day class CCU plant.

Author Contributions: Conceptualization, B.J.L. and J.I.L.; methodology, B.J.L.; validation, C.-S.L.; formal analysis, B.J.L. and S.Y.Y.; writing-original draft preparation, B.J.L. and S.Y.Y.; writing-review and editing, Y.-K.P.; project administration, J.I.L. All authors have read and agreed to the published version of the manuscript. 
Funding: This research was supported and funded by the research project "Development of $\mathrm{CO}_{2}$ Capturing and Mass-Application Storage Technology via Direct Reaction of Power Generation Emission Gas" (project number: 20152010201850) from Korea Energy Technology Evaluation and Planning (KETEP) and the National Institute of Environmental Research as the project "NIER-2019-03-02-0002."

Conflicts of Interest: The authors declare no conflict of interest.

\section{References}

1. Yang, S.; Lei, L.; Zeng, Z.; He, Z.; Zhong, H. An Assessment of Anthropogenic $\mathrm{CO}_{2}$ Emissions by Satellite-Based Observations in China. Sensors 2019, 19, 1118. [CrossRef]

2. Pasricha, N.S. Chapter Six-Conservation Agriculture Effects on Dynamics of Soil C and N under Climate Change Scenario. In Advances in Agronomy; Sparks, D.L., Ed.; Academic Press: Cambridge, UK, 2017; Volume 145, pp. 269-312.

3. Heede, R. Tracing anthropogenic carbon dioxide and methane emissions to fossil fuel and cement producers, 1854-2010. Clim. Change 2014, 122, 229-241. [CrossRef]

4. Mac Dowell, N.; Fennell, P.S.; Shah, N.; Maitland, G.C. The role of $\mathrm{CO}_{2}$ capture and utilization in mitigating climate change. Nat. Clim. Change 2017, 7, 243-249. [CrossRef]

5. Mengis, N.; Matthews, H.D. Non- $\mathrm{CO}_{2}$ forcing changes will likely decrease the remaining carbon budget for $1.5^{\circ} \mathrm{C}$. NPJ Clim. Atmos. Sci. 2020, 3, 19. [CrossRef]

6. Lu, L.; Guest, J.S.; Peters, C.A.; Zhu, X.; Rau, G.H.; Ren, Z.J. Wastewater treatment for carbon capture and utilization. Nat. Sustain. 2018, 1, 750-758. [CrossRef]

7. Budinis, S.; Krevor, S.; Dowell, N.M.; Brandon, N.; Hawkes, A. An assessment of CCS costs, barriers and potential. Energy Strategy Rev. 2018, 22, 61-81. [CrossRef]

8. Snæbjörnsdóttir, S.Ó.; Sigfússon, B.; Marieni, C.; Goldberg, D.; Gislason, S.R.; Oelkers, E.H. Carbon dioxide storage through mineral carbonation. Nat. Rev. Earth Environ. 2020, 1, 90-102. [CrossRef]

9. Cuéllar-Franca, R.M.; Azapagic, A. Carbon capture, storage and utilisation technologies: A critical analysis and comparison of their life cycle environmental impacts. J. $\mathrm{CO}_{2}$ Util. 2015, 9, 82-102.

10. Nguyen, D.N. Carbon Dioxide Geological Sequestration: Technical and Economic Reviews. In SPE/EPA/DOE Exploration and Production Environmental Conference; Society of Petroleum Engineers: San Antonio, TX, USA, 2003; p. 6.

11. Holloway, S. Underground sequestration of carbon dioxide-A viable greenhouse gas mitigation option. Energy 2005, 30, 2318-2333. [CrossRef]

12. Hadi Mosleh, M.; Sedighi, M.; Babaei, M.; Turner, M. 16-Geological sequestration of carbon dioxide. In Managing Global Warming; Letcher, T.M., Ed.; Academic Press: Cambridge, UK, 2019; pp. 487-500.

13. Wilson, T.R.S. The deep ocean disposal of carbon dioxide. Energy Convers. Manag. 1992, 33, $627-633$. [CrossRef]

14. Palmgren, C.R.; Morgan, M.G.; Bruine de Bruin, W.; Keith, D.W. Initial Public Perceptions of Deep Geological and Oceanic Disposal of Carbon Dioxide. Environ. Sci. Technol. 2004, 38, 6441-6450. [CrossRef] [PubMed]

15. Strand, S.E.; Benford, G. Ocean Sequestration of Crop Residue Carbon: Recycling Fossil Fuel Carbon Back to Deep Sediments. Environ. Sci. Technol. 2009, 43, 1000-1007. [CrossRef] [PubMed]

16. Maheshwari, N.; Krishna, P.K.; Thakur, I.S.; Srivastava, S. Biological fixation of carbon dioxide and biodiesel production using microalgae isolated from sewage waste water. Environ. Sci. Pollut. Res. 2020, 27, 27319-27329. [CrossRef] [PubMed]

17. Michiki, $\mathrm{H}$. Biological $\mathrm{CO}_{2}$ fixation and utilization project. Energy Convers. Manag. 1995, 36, 701-705. [CrossRef]

18. Schwander, T.; Schada von Borzyskowski, L.; Burgener, S.; Cortina, N.S.; Erb, T.J. A synthetic pathway for the fixation of carbon dioxide in vitro. Science 2016, 354, 900-904. [CrossRef]

19. Azadi, M.; Edraki, M.; Farhang, F.; Ahn, J. Opportunities for Mineral Carbonation in Australia's Mining Industry. Sustainability 2019, 11, 1250. [CrossRef]

20. Geerlings, H.; Zevenhoven, R. $\mathrm{CO}_{2}$ mineralization-bridge between storage and utilization of $\mathrm{CO}_{2}$. Annu. Rev. Chem. Biomol. Eng. 2013, 4, 103-117. [CrossRef]

21. Global CCS Institute. The Global Status of CCS 2018; Global CCS Institute: Melbourne, Australia, 2018. 
22. Alcalde, J.; Flude, S.; Wilkinson, M.; Johnson, G.; Edlmann, K.; Bond, C.E.; Scott, V.; Gilfillan, S.M.V.; Ogaya, X.; Haszeldine, R.S. Estimating geological $\mathrm{CO}_{2}$ storage security to deliver on climate mitigation. Nat. Commun. 2018, 9, 2201. [CrossRef]

23. Intergovernmental Panel on Climate Change. IPCC Special Report on Carbon Dioxide Capture and Storage; Intergovernmental Panel on Climate Change: Washington, DC, USA, 2005.

24. Finkenrath, M. Cost and Performance of Carbon Dioxide Capture from Power Generation; no.2011/05; International Energy Agency: Paris, France, 2011.

25. House, K.Z.; Harvey, C.F.; Aziz, M.J.; Schrag, D.P. The energy penalty of post-combustion $\mathrm{CO}_{2}$ capture \& storage and its implications for retrofitting the U.S. installed base. Energy Environ. Sci. 2009, 2, $193-205$.

26. Irlam, L. Global Costs of Carbon Capture and Storage. Available online: https://www.globalccsinstitute.com/ archive/hub/publications/201688/global-ccs-cost-updatev4.pdf (accessed on 4 June 2017).

27. Zhang, Z.; Pan, S.-Y.; Li, H.; Cai, J.; Olabi, A.G.; Anthony, E.J.; Manovic, V. Recent advances in carbon dioxide utilization. Renew. Sustain. Energy Rev. 2020, 125, 109799. [CrossRef]

28. Lee, J.H.; Lee, D.W.; Gyu, J.S.; Kwak, N.-S.; Lee, I.Y.; Jang, K.R.; Choi, J.S.; Shim, J.-G. Economic Evaluation for the Carbon Dioxide-involved Production of High-value Chemicals. Korean Chem. Eng. Res. 2014, 52, 347-354. [CrossRef]

29. McCord, S.A.; Zaragoza, A.V.; Sanderson, P.; Armstrong, K.; Styring, P.; Hills, C.; Carey, P.; Osbourne, M.; Müller, L.; Bardow, A. Global $\mathrm{CO}_{2}$ Initiative Complete Mineralization Study 2018. Environ. Sci. 2019. [CrossRef]

30. Zaragoza, A.V.; McCord, S.; Styring, P.; Cremonese, L.; Strunge, T.; Sick, V. Interpretation of LCA Results: A Worked Example on a $\mathrm{CO}_{2}$ to Fertilizer Process; Technische Universität Berlin: Berlin, Germany, 2020.

31. Yadav, N.; Seidi, F.; Crespy, D.; D’Elia, V. Polymers Based on Cyclic Carbonates as Trait d'Union Between Polymer Chemistry and Sustainable $\mathrm{CO}_{2}$ Utilization. ChemSusChem 2019, 12, 724-754. [CrossRef] [PubMed]

32. Kätelhön, A.; Meys, R.; Deutz, S.; Suh, S.; Bardow, A. Climate change mitigation potential of carbon capture and utilization in the chemical industry. Proc. Natl. Acad. Sci. USA 2019, 116, 11187-11194. [CrossRef]

33. Costentin, C.; Drouet, S.; Robert, M.; Savéant, J.-M. A Local Proton Source Enhances $\mathrm{CO}_{2}$ Electroreduction to $\mathrm{CO}$ by a Molecular Fe Catalyst. Science 2012, 338, 90-94. [CrossRef]

34. Peterson, A.A.; Nørskov, J.K. Activity Descriptors for $\mathrm{CO}_{2}$ Electroreduction to Methane on Transition-Metal Catalysts. J. Phys. Chem. Lett. 2012, 3, 251-258. [CrossRef]

35. Back, S.; Kim, H.; Jung, Y. Selective Heterogeneous $\mathrm{CO}_{2}$ Electroreduction to Methanol. ACS Catal. 2015, 5, 965-971. [CrossRef]

36. Fan, J.-L.; Wei, S.; Yang, L.; Wang, H.; Zhong, P.; Zhang, X. Comparison of the LCOE between coal-fired power plants with CCS and main low-carbon generation technologies: Evidence from China. Energy 2019, 176, 143-155. [CrossRef]

37. Aliyon, K.; Hajinezhad, A.; Mehrpooya, M. Energy assessment of coal-fired steam power plant, carbon capture, and carbon liquefaction process chain as a whole. Energy Convers. Manag. 2019, 199, 111994. [CrossRef]

38. Sick, V.; Armstrong, K.; Cooney, G.; Cremonese, L.; Eggleston, A.; Faber, G.; Hackett, G.; Kätelhön, A.; Keoleian, G.; Marano, J.; et al. The Need for and Path to Harmonized Life Cycle Assessment and Techno-Economic Assessment for Carbon Dioxide Capture and Utilization. Energy Technol. 2019, 1901034. [CrossRef]

39. Chrysostomou, C.; Kylili, A.; Nicolaides, D.; Fokaides, P.A. Life Cycle Assessment of concrete manufacturing in small isolated states: The case of Cyprus. Int. J. Sustain. Energy 2017, 36, 825-839. [CrossRef]

40. Energy Information Administration. Levelized Cost and Levelized Avoided Cost of New Generation Resources in the Annual Energy Outlook 2020; USA Energy Information Administration: Washington, DC, USA, 2020.

41. Yeo, T.Y.; Bu, J. Mineral Carbonation for Carbon Capture and Utilization. In An Economy Based on Carbon Dioxide and Water: Potential of Large Scale Carbon Dioxide Utilization; Aresta, M., Karimi, I., Kawi, S., Eds.; Springer International Publishing: Cham, Switzerland, 2019; pp. 105-153.

42. Tribe, M.A.; Alpine, R.L.W. Scale economies and the “0.6 rule”. Eng. Costs Prod. Econ. 1986, 10, $271-278$. [CrossRef]

43. Kang, K.K.; Kim, J.W. Environmental Impact and Economic Analysis for Expanding Young-Heung Power Plants; Korea Environment Institute: Sejong, Korea, 2012; pp. 1-86.

(C) 2020 by the authors. Licensee MDPI, Basel, Switzerland. This article is an open access article distributed under the terms and conditions of the Creative Commons Attribution (CC BY) license (http://creativecommons.org/licenses/by/4.0/). 